\title{
Effect of Garlic (Allium sativum) on Production Performances and Carcass Traits of Nandanam Broiler-2
}

\author{
K. Sangilimadan ${ }^{*}$, R. Richard Churchil ${ }^{1}$, K. Premavalli ${ }^{2}$ and A.V. Omprakash ${ }^{3}$ \\ ${ }^{1}$ Department of Poultry Science, Madras Veterinary College, Chennai-7, India \\ ${ }^{2}$ Post Graduate Research Institute of Animal Sciences, Kattupakkam, Chennai-203, India \\ ${ }^{3}$ Poultry Research Station (PRS), Tamil Nadu Veterinary and Animal Sciences University, \\ $M M C$, Chennai-51, India \\ *Corresponding author
}

\begin{tabular}{|c|c|}
\hline & A B S T R A C T \\
\hline & \multirow{6}{*}{$\begin{array}{l}\text { A study was conducted to the effect of garlic with two different levels on the growth } \\
\text { performances and carcass characteristics of NandanamBroiler- } 2 \text {. A total of } 84 \text { day old } \\
\text { NandanamBroiler- } 2 \text { chicks were randomly allotted into three treatments with two } \\
\text { replicates which contained } 14 \text { chicks in each replicate for } 8 \text { weeks experimental period } \\
\text { The dietary treatments were formulated as a control (T1), } 0.25 \% \text { (T2), } 0.50 \% \text { (T3) garlic } \\
\text { paste with basal diet. The data on production parameters like weekly body weight, feed } \\
\text { consumption and mortality were recorded. At the end of the } 8 \text { weeks of age, six birds } \\
\text { ( } 3 \text { male and } 3 \text { female) were randomly selected and subjected to slaughter studies to } \\
\text { determine the carcass characteristics. The birds supplemented with } 0.25 \% \text { garlic paste } \\
\text { (T2) had significantly higher body weight, better feed efficiency and livability compared to } \\
\text { control (T1). However, no significant difference was observed in terms of carcass traits in } \\
\text { this experiment. The dietary supplementation of } 0.5 \% \text { garlic (T3) resulted in significan } \\
\text { (P }<0.01 \text { ) improvement in terms of thigh yield as compared to T1 and T2. On the other } \\
\text { hand, significant }(\mathrm{P}<0.01 \text { ) improvement in wing yield was noticed with dietary } \\
\text { supplementation of } 0.25 \% \text { garlic (T2) as compared to T1 and T3. It can be concluded tha } \\
\text { garlic paste supplementation at the level of } 0.25 \% \text { in the diet of coloured broilers can result } \\
\text { in substantial improvements in production performances. }\end{array}$} \\
\hline Keywords & \\
\hline $\begin{array}{l}\text { Chicken, Garlic, } \\
\text { Body weight, } \\
\text { Livability, Feed } \\
\text { efficiency }\end{array}$ & \\
\hline Article Info & \\
\hline $\begin{array}{l}\text { Accepted: } \\
\text { 17 March } 2019 \\
\text { Available Online: } \\
10 \text { April } 2019\end{array}$ & \\
\hline & \\
\hline
\end{tabular}

\section{Introduction}

Feed additives are a group of nutrient and non-nutrient compounds which helps in improving the efficiency of feed utilization and thus reducing the cost of feed. In the past, antibiotics were the most routinely used feed additives. However, now -a-days use of antibiotics is not only limited but their use in livestock and poultry industry also have been banned in many countries due to the reasons like alteration of natural gut microbes and drug resistance in bacteria and humans. As, a result, to replace them without adversely affecting the performance of birds, natural growth promotes such as prebiotics, symbiotic, enzymes, plant extracts etc. can be used to feed the broilers (Borazjanizadeh $e t$ 
al.,2011).Garlic (Allium sativum) has been used as a spice and native medicine for many years. It possess antibacterial, antiparasitic, antiviral, antioxidant, anticholesteremic, anticancerous and vasodilator characteristics (Hanieh et al., 2010). Garlic powder as a natural growth promoter can be potential alternative for common artificial growth promoters like antibiotics and in this respect, it can improve growth rate, feed conversion ratio (FCR), and carcass characteristics (Makwana et al., 2015; Demir et al., 2003; Lewis et al., 2003; Tollba and Haesan, 2003). The active ingredient in garlic is the plant chemical allicin, which rapidly decompose to several volatile organosulphur compounds with bioactivity (Chang and Cheong, 2008). Thus the present study was designed to observe the potential of incorporating different levels of garlic as a phytogenic growth promoter in NandanamBroiler-2 chicken.

\section{Materials and Methods}

The study was carried out at Poultry Research Station, Madavaram Milk Colony, Tamil Nadu Veterinary and Animal Sciences University, Chennai, located between $13^{\circ}-9^{\prime}$ and $13^{\circ}-15^{\prime} \mathrm{N}$ and longitudes $80^{\circ}-14^{\prime}$ and $80^{\circ}$ $24^{\prime}$ E with an altitude of 22 meters above mean sea level. Chennai has a hot and humid climate, classified as "Tropical Maritime Monsoon" type. The average annual rainfall is $130 \mathrm{~mm}$ and pends mostly on the North East monsoon. Average temperature was $28.4^{\circ} \mathrm{C}$ during the study period (December to February). The relative humidity was high throughout the year in range of 65- 85 percent.

\section{Experimental design}

The standard recommended commercial broiler diet was prepared as per BIS 2007 broiler standard with similar nutrient composition for all the treatments. The design of experiment is presented in Table 1. The control diet was formulated without supplementation of any antibiotics, growth promoters or yeast, prebiotics (T1). The experimental diets were prepared by supplementing the control diet with two different levels of garlic. The required amount of garlic paste were prepared and weighed and initially mixed with small quantity of feed and then mixed with bulk quantity of feed to get the final concentration of 0.25 and 0.50 percent in (T2) and (T3) respectively. All the diets were isocaloric and is on itrogenous.

\section{Management of experimental birds}

The chicks were reared upto three weeks of age in a brooder cage and later transferred to large size cage and maintained upto the experimental period of 8 weeks of age. All the chicks were provided with uniform floor, feeder and water space and were reared under standard management condition throughout the experimental period. Brooding was done in cages having dimensions of $75 \times 50 \times 30 \mathrm{~cm}$ in size from 1-21 days of age.

All brooding managements were made well before the arrival of chicks. All the chicks were provided with uniform facilities using 40 watt incandescent bulb in each cage. From 4-6weeks of age the bird were reared in cages having dimensions of $90 \times 50 \times 30 \mathrm{~cm}$ and from 7-8 weeks of age was done in cages having dimensions of 120x 50x 30cm in size.

The feed and water were provided ad libitum during the experimental periods. Standard management practices were adopted in all the experimental groups. Chicks were provided with 24 hours light during the first 3 days of brooding period followed by 23 hours of light till 2 weeks of age. The vaccination schedule followed is presented in Table 2. 


\section{Statistical analysis}

The statistical analysis was done using Sigmaplot version 11.0 (Systat Software Inc., USA). Data sets were first tested for normality by Shapiro-Wilk's normality test and analysed by RC2analysis of variance (ANOVA) with general linear model (GLM). All pair wise differences in mean were compared by Tukey post hoc test.

\section{Results and Discussion}

The effect of supplementation of garlic paste on body weight, feed efficiency, livability, carcass traits and cut-up-parts were presented in Tables 3-6.

\section{Body weight}

Mean second week body weight of Nandanam Broiler - 2 were $(\mathrm{P}<0.05)$ significantly higher in $0.25 \%$ garlic supplemented groups (T2) than control (T1). There was no significant difference in the body weight during 4 and 6 weeks of age. However, birds fed with garlic paste at the level of $0.25 \%$ (T2) and $0.50 \%$ (T3) had body weights heavier $(\mathrm{P}<0.05)$ than those in control group (T1).The groups supplemented with garlic paste of $0.25 \%$ (T2) and $0.50 \%(\mathrm{~T} 3)$ had significantly $(\mathrm{P}<0.05)$ higher body weights than control (T1) at 8 weeks of age (Table 3). The present findings at 2 weeks of age on body weight is in agreement with the findings of Aji et al., (2011), who also reported that administration of $100 \mathrm{mg}$ of garlic resulted in improved body weight gain at 14 days of age in broiler chicks. Similar findings were also reported by Suriya et al., (2012) broilers fed with $0.25 \%$ and $0.5 \%$ garlic at 21 days of age. Patel et al., (2017) reported that basal diet supplemented with $0.5 \%$ garlic bulb powder significantly $(\mathrm{P}<0.05)$ improved body weight compared to control groups upto 42 days in broilers. Similar, findings were observed Makwana et al., (2015), who conducted research on garlic powder supplementation at 0.1 and $0.5 \%$ of in basal diet and reported that body weight of the broiler birds was significantly higher in $0.1 \%$ as compared to $0.5 \%$ and control. The total body weight of cobb- 400 broilers upto 6 weeks of age fed with a diet containng $1.0 \%$ garlic showed significantly $(\mathrm{P}<0.05)$ higher values as compared to control (Karangiya et al., 2016). Pourali et al., (2010) suggested that allicin in garlic promotes the performance of the intestinal flora thereby improving digestion and enhancing the utilization of energy, leading to improved growth. On the other hand, a contradictory report of no significant effect on body weight was observed by Rahimi et al., (2011) with garlic supplementation of broiler diet. Onibi et al., (2009) and Fadlalla et al., (2010) also reported that garlic powder had no significant effect on the body weight gain of birds.

\section{Feed efficiency}

Experimental birds in (T2) group showed significantly $(\mathrm{P}<0.01)$ better feed conversion ratio as compared to T1and $\mathrm{T} 3$ groups as presented in Table 3. The birds fed with basal diet (T1) and basal diet supplemented with $0.50 \%$ garlic (T3) had similar FCR. This present findings are agreement with those of Onu (2010), who showed that ginger and garlic supplementation at $0.25 \%$ level in broiler finisher diets enhanced the feed conversion ratio. Makwana et al., (2015)stated that better feed conversion ratio $(\mathrm{P}<0.01)$ was observed in birds receiving $0.1 \%$ garlic as compared to those receiving either $0.5 \%$ garlic or control. Patel et al, (2017) reported that broilers supplemented with $0.5 \%$ garlic had better FCR than $0.5 \%$ garlic and fenugreek seed powder supplemented group. Suriya et al., (2012) reported that overall performance of $0.5 \%$ and $0.1 \%$ garlic supplementation improved feed conversion ratio when compared to control. The feed conversion ratio of garlic powder mixed in the feed at $14 \mathrm{~g} / \mathrm{kg}$ of basal diet had a 
significant $(\mathrm{P}<0.05)$ increase than other treatments (Oleforuh-Okoleh et al., (2014). On the other hand, Aji et al., (2011) reported non-significant effect of dietary garlic on feed conversion ratio. Although, contrary results were obtained by Onibi et al., (2009) and Fadlalla et al., (2010), who reported that garlic powder had no significant effect on the feed conversion ratio of birds.

\section{Livability}

The mean percent cumulative livability upto 8 weeks of experiment is shown in Table 4. Experimental birds in (T3) and (T1) had significantly $(\mathrm{P}<0.05)$ better livability at 2 week of age compared to (T2). Whereas remaining periods of experiment at 4,6 and 8 week of age were significantly $(\mathrm{P}<0.01)$ better livability on $0.25 \%$ garlic (T2) group compared with $0.5 \%$ garlic (T3) and control (T1) group. The present findings were closely agreed with Patel et al., (2017) who have reported that the mean percent livability was $95 \%$ with inclusion of $0.5 \%$ garlic in broiler diet. The present finding concurred with previous report of Makwana et al., (2015) who have reported that the livability of $98.33 \%$ at $0.5 \%$ garlic included in broiler diets. The results of the present study were supported by the earlier findings of Fadlalla et al., (2010). In present study, lower mortality in garlic fed birds might be due to antimicrobial action of garlic (Ankri and Mirelman, 1999).

\section{Carcass traits}

The carcass parameters studied in this experiment are shown in Table 5. The present findings revealed non- significant $(\mathrm{P}>0.05)$ differences among different dietary treatment groups in terms of blood loss, feather loss, weights of liver, heart and gizzard, and eviscerated and ready-to-cook Aji et al., (2011) also reported non-significant effect of garlic supplementation on dressing percentage in broilers. Similarly, Abbas (2010) and Awadein et al., (2010) reported that weights of liver, gizzard, heart and spleen had nonsignificant $(\mathrm{P}>0.05)$ differences in garlic and fenugreek supplemented broilers. Makwana et al., (2015) reported non-significant effect due to $0.1 \%$ and $0.5 \%$ garlic supplementation on shrinkage loss, blood loss, feather loss, eviscerated yield, relative weights of heart, liver, gizzard and giblets. In contrast to the present findings, Ashayerizadeh et al., (2009) and Makwana et al., (2015) reported significant $(\mathrm{P}<0.05)$ increase in dressing percentage on garlic supplementation in broilers.

\section{Cut-up-parts}

The cut-up-parts of Nandanam Broiler - 2 of different treatment groups were presented in Table 6. The present findings revealed significantly $(\mathrm{P}<0.05)$ higher thigh percentage were observed in (T3) as compared (T1) and (T2). In contrast to present findings, Ashagerizadeh et al., (2009) and Javed et al., (2009) demonstrate that garlic powder added into broiler feed and water did not change thigh weight. The percent wing yield was significantly $(\mathrm{P}<0.05)$ lower in $(\mathrm{T} 3)$ as compared to $\mathrm{T} 1$ and $\mathrm{T} 2$. The similar finding of improved leg weight was observed by Javed et al., (2009) in a 35days experimental trail. In this study, broilers were supplemented with aqueous extract of medicinal plants containing garlic at the rate of $10 \mathrm{ml} / \mathrm{litter}$ of drinking water.

The other weights and cut-up-parts were not affected in Nandanam Broiler -2due to supplementation of different levels of dietary garlic. On the other hand, Raeesi et al., (2010) reported a significant effect on the carcass parts of broilers fed with garlic. Pourali et al., (2010) reported that the carcass parts were not affected by garlic supplementation and the finding is in agreement with the present findings. 
Table.1 Experimental design

\begin{tabular}{|l|l|c|c|}
\hline Group & Treatment & Replicates & No. of birds \\
\hline T1 & Basal diet (control) & 2 & 28 \\
\hline T2 & Basal diet with 0.25\% garlic paste & 2 & 28 \\
\hline T3 & Basal diet with 0.50\% garlic paste & 2 & 28 \\
\hline
\end{tabular}

Table.2 Vaccination schedule

\begin{tabular}{|c|c|c|c|}
\hline Age & Type of Vaccine & Route of administration & Dose \\
\hline $\mathbf{5 - 7}$ days & RD or Newcastle- RDVF & Intra ocular/ Intra nasal & 1 drop \\
\hline $\mathbf{1 8}^{\text {th }}$ day & $\begin{array}{c}\text { IBD Vaccine } \\
\text { (Intermediate Georgia) }\end{array}$ & Intra ocular/ Intra nasal & 1 drop \\
\hline $\mathbf{2 8}^{\text {th }}$ day & RDV-LaSota strain & Drinking water & - \\
\hline $\mathbf{5 6}^{\text {th }}$ day & RDVK or R2B & S/C & $0.5 \mathrm{ml}$ \\
\hline
\end{tabular}

Table.3 Effect of supplementation of garlic on production performance of Nandanam broiler $2($ Mean \pm S.E)

\begin{tabular}{|l|c|c|c|}
\hline \multicolumn{1}{|c|}{ Production performance } & T1 (Control) & $\begin{array}{l}\text { T2(Feed plus } \\
\mathbf{0 . 2 5 \%} \text { garlic) }\end{array}$ & $\begin{array}{l}\text { T3(Feed plus } \\
\text { 0.50\% } \\
\text { garlic) }\end{array}$ \\
\hline Hatch weight $(\mathbf{g})^{\mathbf{N S}}$ & $40.05 \pm 0.58$ & $41.06 \pm 0.68$ & $41.88 \pm 0.71$ \\
\hline $\mathbf{2}^{\text {nd }}$ week weight $(\mathbf{g})^{* *}$ & $131.79^{\mathrm{b}} \pm 6.25$ & $172.37^{\mathrm{a}} \pm 3.48$ & $110.89^{\mathrm{c}} \pm 5.82$ \\
\hline $\mathbf{4}^{\text {th }}$ week weight $(\mathbf{g})^{\mathbf{N S}}$ & $327.60 \pm 14.94$ & $336.44 \pm 17.07$ & $311.00 \pm 12.72$ \\
\hline $\mathbf{6}^{\text {th }}$ week weight $\left.\mathbf{( g )}\right)^{\mathbf{N S}}$ & $608.04 \pm 23.87$ & $645.33 \pm 13.87$ & $613.11 \pm 12.39$ \\
\hline $\mathbf{8}^{\text {th }}$ week weight $(\mathbf{g})^{*}$ & $993.08^{\mathrm{b}} \pm 38.27$ & $1089.00^{\mathrm{a}} \pm 22.92$ & $1016.46^{\mathrm{a}} \pm 21.29$ \\
\hline Feed efficiency** & $2.54^{\mathrm{b}} \pm 0.10$ & $2.16^{\mathrm{a}} \pm 0.04$ & $2.45^{\mathrm{b}} \pm 0.05$ \\
\hline
\end{tabular}

** - Significant $(\mathrm{P}<0.01)$; *Significant $(\mathrm{P}<0.05)$; NS-Not Significant

Mean value within each row bearing common superscripts do not differ significantly $(\mathrm{P}>0.05)$ 
Table.4 Effect of supplementation of garlic on liveability of NandanamBroiler- 2 $($ Mean \pm S.E)

\begin{tabular}{|l|l|l|l|}
\hline Age & T1 (Control) & $\begin{array}{l}\text { T2(Feed plus } \\
\text { 0.25\% garlic) }\end{array}$ & $\begin{array}{l}\text { T3(Feed plus } \\
\mathbf{0 . 5 0 \%} \text { garlic) }\end{array}$ \\
\hline First Week* & $100.00^{\mathrm{a}} \pm 0.00$ & $98.47^{\mathrm{b}} \pm 0.72$ & $100.00^{\mathrm{a}} \pm 0.00$ \\
\hline Fourth Week $* *$ & $90.30^{\mathrm{c}} \pm 0.66$ & $96.43^{\mathrm{a}} \pm 0.00$ & $92.86^{\mathrm{b}} \pm 0.00$ \\
\hline Sixth Week $* *$ & $87.76^{\mathrm{c}} \pm 0.72$ & $96.43^{\mathrm{a}} \pm 0.00$ & $92.86^{\mathrm{b}} \pm 0.00$ \\
\hline Eighth Week $* *$ & $85.71^{\mathrm{c}} \pm 0.00$ & $96.43^{\mathrm{a}} \pm 0.00$ & $92.86^{\mathrm{b}} \pm 0.00$ \\
\hline
\end{tabular}

$* *$ Significant $(\mathrm{P}<0.01) *$ - Significant $(\mathrm{P}<0.05)$

Mean value within each row bearing common superscripts do not differ significantly $(\mathrm{P}>0.05)$

Table.5 Effect of garlic on carcass traits of NandanamBroiler-2(Mean \pm S.E)

\begin{tabular}{|c|c|c|c|}
\hline Carcass Traits & T1 (Control) & $\begin{array}{l}\text { T2(Feed plus } \\
0.25 \% \text { garlic) }\end{array}$ & $\begin{array}{l}\text { T3(Feed plus } \\
0.50 \% \text { garlic) }\end{array}$ \\
\hline Live weight $(g)^{\mathrm{NS}}$ & $1176.33 \pm 58.90$ & $1329.33 \pm 106.70$ & $1355.50 \pm 48.30$ \\
\hline Blood loss $(\%)^{\mathrm{NS}}$ & $4.35 \pm 0.17$ & $4.73 \pm 0.17$ & $4.68 \pm 0.37$ \\
\hline Feather loss $(\%)^{\mathrm{NS}}$ & $7.31 \pm 0.42$ & $6.54 \pm 0.40$ & $6.26 \pm 0.16$ \\
\hline Liver weight $(\%)^{\mathrm{NS}}$ & $2.96 \pm 0.28$ & $2.98 \pm 0.22$ & $2.71 \pm 0.09$ \\
\hline Heart weight $(\%)^{\mathrm{NS}}$ & $0.59 \pm 0.10$ & $0.57 \pm 0.03$ & $0.55 \pm 0.04$ \\
\hline Gizzard weight $(\%)^{\mathrm{NS}}$ & $2.85 \pm 0.19$ & $2.53 \pm 0.07$ & $2.39 \pm 0.13$ \\
\hline Eviscerated weight (\%) ${ }^{\text {NS }}$ & $61.70 \pm 0.70$ & $62.70 \pm 1.25$ & $61.66 \pm 1.66$ \\
\hline Giblet weight $(\%)^{\mathrm{NS}}$ & $6.40 \pm 0.41$ & $6.08 \pm 0.30$ & $5.65 \pm 0.20$ \\
\hline R-to-C- weight $(\%)^{\mathrm{NS}}$ & $68.10 \pm 0.69$ & $68.78 \pm 1.10$ & $67.31 \pm 1.75$ \\
\hline $\begin{array}{l}\text { Small intestine length } \\
(\mathrm{cm})^{\mathrm{NS}}\end{array}$ & $168.50 \pm 4.88$ & $170.75 \pm 5.87$ & $173.33 \pm 4.39$ \\
\hline
\end{tabular}

NS-Not Significant $(\mathrm{P}>0.05)$

Table.6 Effect of garlic on cut-up-parts of NandanamBroiler-2(Mean \pm S.E)

\begin{tabular}{|c|c|c|c|}
\hline Cut-up-Parts & T1 (Control) & $\begin{array}{l}\text { T2(Feed plus } \\
0.25 \% \text { garlic) }\end{array}$ & $\begin{array}{l}\text { T3(Feed plus } \\
0.50 \% \text { garlic) }\end{array}$ \\
\hline Breast weight $(\%)^{\mathrm{NS}}$ & $28.62 \pm 1.21$ & $28.62 \pm 1.21$ & $28.62 \pm 1.21$ \\
\hline Back weight $(\%)^{\text {NS }}$ & $18.09 \pm 1.10$ & $17.18 \pm 0.45$ & $16.23 \pm 0.46$ \\
\hline Thigh weight $(\%)^{* *}$ & $18.72^{\mathrm{a}} \pm 0.51$ & $16.07^{\mathrm{b}} \pm 0.40$ & $18.92^{\mathrm{a}} \pm 0.46$ \\
\hline $\begin{array}{l}\text { Drumstick weight } \\
\%)^{\mathrm{NS}}\end{array}$ & $16.73 \pm 0.68$ & $15.59 \pm 0.38$ & $17.22 \pm 0.47$ \\
\hline Neck weight $(\%)^{\mathrm{NS}}$ & $8.29 \pm 0.51$ & $9.59 \pm 0.54$ & $8.20 \pm 0.48$ \\
\hline Wing weight $(\%)^{* *}$ & $14.59^{\mathrm{a}} \pm 0.29$ & $15.13^{\mathrm{a}} \pm 0.64$ & $12.64^{\mathrm{b}} \pm 0.34$ \\
\hline
\end{tabular}

** - $(\mathrm{P}<0.01)$ Highly Significant NS-Not Significant $(\mathrm{P}>0.05)$

Mean values sharing any one common superscript in a row or column do not differ significantly $(\mathrm{P}>0.05)$

\section{Small intestine length}

The small intestine length $(\mathrm{cm})$ at $8^{\text {th }}$ week of age showed statistically non-significant
$(\mathrm{P}>0.05)$ differences among garlic $(0.25 \%$ and $0.50 \%)$ fed groups and control group (Table 6). Similarly, (Patel et al., 2017) also reported that the length of intestine and caecum had 
non-significant $(\mathrm{P}>0.05)$ difference due to supplementation of garlic and fenugreek alone and in combination. Javandel et al., (2008) reported non-significant effect of garlic on intestine length of broilers. Likewise, Abbas (2010) reported non-significant effect of fenugreek on intestine and caecum lengths in broilers.

It could be concluded that $0.25 \%$ garlic supplementation can benefit broilers in terms of body weight, feed efficiency and livability than $0.5 \%$ level. Therefore garlic supplementation at $0.25 \%$ level in feed can result in better production efficiency and economics in broiler production.

\section{References}

Abbas, R.J., (2010). Effect of using fenugreek, parsley and sweet basil seeds as feed additives on the performance of broiler chickens. Int. J. Poult. Sci., 9 (3):278-282.

Aji, S.B., Ignatius, K., Ado, Y.A., Nuhu, J.B., Abdulkarim, A., Aliyu, U., Gambo, M.B., Ibrahim, M.A., Abubakar, H., Bukar, M., Imam, H.M. and P.T. Numan, 2011. Effect of feeding onion and garlic on some performance characteristics of broiler chicken. Res. $J$. Poult. Sci., 4(2): 22-27

Ankri, S., and Mirelman, D. 1999. Antimicrobial properties of allicin from garlic. Microbes Infect., 2: 125-129 .

Ashayerizadeh, A., Dastar, B., Rahmatnejad, E., Shargh, M.S., Ashayerizadeh, O. and Hossaini, S.M.R. 2009. Use of garlic (Allium sativum), black cumin seeds (Nigella sativa L.) and wild mint (Mentha longifolia) in broiler chicken diets.J.Anim. Vet. Adv., 8: 1860-63.

Awadein, N.B., Eid, Y.Z. and Abd El-Ghany, A.F.2010. Effect of dietary supplementation with phytoestrogens sources before sexual maturity on productive performance of mandarahhens. Egyptian Poult. Sci. J., 30: $829-46$

Borazjanizadeh, M., Eslami, M., Bojarpour, M., Chaji, M. and Fayazi, J. 2011.The effect of clove and oregano on economic value of broiler chickens diet under hot weather of Khuzesta. J. Ani. Vet. Advance. 10 (2): 169-173.

Chang, K.J., and Cheong, S.H. 2008. Volatile organosulphur and nutrient compounds from garlic by cultivating areas and processing methods. Fed. Anim. Soc. Exp.Bio. J. 22: 1108-112.

Demir,E., Sarica, S., Ozean, M.A. and Suicmez, M. 2003. The use of natural feed additives as alternative for an antibiotic growth promoter in broiler diets. Br. J. Poult. Sci. 44: 44-45.

Fadlalla, IM.T., Mohammed, B.H and Bakhiet, A.O. 2010. Effect of feeding garlic on the performance and immune of broilers.Asian J. Poult.Sci.4 (4) : 182189.

Hanieh, H., Narabara, K., Piao, M., Gerile, C., Abe, A. and Kondo, Y. 2010.Modulatory effects of two levels of dietary Alliums on immune responses.Animal Sci.J.81 : 673-680.

Javed, M., Durrani, F., Hafeez, A., Khan, R.U., and Ahmed, I. 2009.Effect of aqueous extract of plant mixtures on carcass quality of broiler chicks.ARPNJ.Agri.andBio.Sci.4: 37-40.

Javendal, F., Blaridshad, B., Seifarati, J., Pourrahimi, A.H. and Baniyaghoub, S. 2008. The favorite dosage of garlic meal as a feed addictive in broiler chickens ration.Pak.J.Biol.Sci., 11 (3) : 17461749.

Karangiya, V.K., Savsani, H.H., Shrikant Soma Patil, Garg, D.D., Murtht, K.S, Ribadiya, N.K and Vekariya, S.J. 2016. Effect of dietary supplementation of garlic, ginger and their combination of feed intake, growth performance and 
economics in commercial broilers.Vet.World.9: 245-250.

Lewis, M., Choudhary, R.S and J.K.Vaishnav, 2003 Effect of plant extract on growth performance of male broiler chickens. Br. Poult. Sci., 44: 43-44

Makwana, R.B., Raval, A.P., Chauchan, H.D., Kulkarni, R.C., Srivastava, A.K, Bhagwat, S.R. and Rajgor, B.B. 2015. Effects of garlic (Allium sativum) supplementation on growth performance, carcass characteristics and economics of broilers. J. Anim. Res., 5 (4): 843-848.

Oleforuh-Okoleh, V.U., Chukwu, G.C. and Adeolu, A.I. 2014.Effect of ground ginger and garlic on the growth performance, carcass quality and economics of production of broiler chickens.Glob.J.Biosci.Biotechnol., 3 (3) :225-229.

Onibi, G.E., Oluwatoyin, E., Adebisi, A., Fajemisin, N., Ayode, V and Adetun, J.I. 2009. Response of broiler chickens in terms of performance and meat quality to garlic (Allium satuvum) supplementation. Afr. J. Agr. Res. 4 (5): 511-517.

Onu, P.N., 2010. Evaluation of two herbal spices as feed additives for finisher broilers. Biotech.Anim.Husb., 26 (5-6) : 383-392.

Patel, R.M., Garg, D.D., Vahora, S.G., Raval, A.P and Choubey M. 2017. Effect of dietary supplementation of garlic (Allium sativum) and Fenugreek
(Trionellafoenum-graecum L.) seed powder on growth performance, carcass characteristics and economics of feeding in broilers. J. Anim. Res. 7 (2): 313-318.

Pourali, M., Mirghelenji, S.A., and Kermanshahi, H.2010. Effects of garlic powder on productive performance and immune response of broiler chickens challenged with Newcastle disease virus. Global Veterinarian, 4 (6): 616-21.

Raeesi, M., Hoseini-Aliabad, A., Roofchaee, A., Zareshahneh, A. and Pirali, S. 2010. Effect of periodically use of garlic (Allium sativum) powder on performance and carcass characteristics of broiler chickens. World Academy of Sci. Engin. Tech., 44.

Rahimi, S., Teymouri, Z.Z., Karimi, T.M.A., Omidbaigi, R. and Rokni, H. 2011. Effect of the three herbal extracts on growth performance, immune system, blood factors and intestinal selected bacterial population in broiler chickens. J. Agric. Sci. Technol., 13: 527-39.

Suriya, R., Zulkifli, I. and Alimon, A.R. 2012. The effect of dietary inclusion of herbs as growth promoter in broiler chickens. J. Anim. Vet. Adv., 11(3): 346-50.

Tollba, A.A.H and Hassan, M.S.H. 2003. Using some natural additives to improve physiological and productive performance of broiler chicks under high temperature conditions. Black cumin (Nigells sativa) or Garlic (Allium sativum). Poultry Sci., 23: 327-40.

\section{How to cite this article:}

Sangilimadan, K., R. Richard Churchil, K. Premavalli and Omprakash, A.V. 2019. Effect of Garlic (Allium sativum) on Production Performances and Carcass Traits of Nandanam Broiler2. Int.J.Curr.Microbiol.App.Sci. 8(04): 2531-2538.

doi: https://doi.org/10.20546/ijcmas.2019.804.295 